\title{
Prevalence, host range, and spatial distribution of black band disease in the Maldivian Archipelago
}

\author{
Simone Montano ${ }^{1,2, *}$, Giovanni Strona ${ }^{1,2}$, Davide Seveso ${ }^{1,2}$, Paolo Galli ${ }^{1,2}$ \\ ${ }^{1}$ Department of Biotechnologies and Biosciences, University of Milan - Bicocca, Piazza della Scienza 2, 20126 Milan, Italy \\ ${ }^{2}$ MaRHE Centre (Marine Research and High Education Centre), Magoodhoo Island, Faafu Atoll, Republic of Maldives
}

\begin{abstract}
Little research has been conducted on diseases affecting reef-building corals in the central Indian Ocean. During 2010 and 2011, we performed a quantitative assessment of black band disease (BBD) in the central Republic of Maldives. Distribution, host range, and prevalence of BBD were investigated at 6 coral islands (Magoodhoo, Adanga, Ihuru, Vabbinfaru, Thudufushi, and Athuruga) belonging to 3 different atolls. BBD was found to be widespread among the atolls. All the islands showed a prevalence lower than $0.5 \%$. Magoodhoo Island showed the highest mean disease prevalence. In the whole surveyed area, shallow sites showed higher overall mean BBD prevalence than deep ones. BBD was recorded from 6 scleractinian families (Acroporidae, Faviidae, Poritidae, Siderastreidae, Agariciidae, Fungiidae) and 13 scleractinian genera. Two of them, Gardineroseris and Sandalolitha, constitute new records for the disease. The siderastreid Psammocora (BBD prevalence: $5.33 \pm 1.41 \%$, mean \pm SE) was the most affected genus, followed by Goniopora $(2.7 \pm 1.3 \%)$. BBD prevalence was positively correlated to the respective host density in both genera. Favites and Acropora were the less affected genera (both $<0.1 \%$ ). Although we observed an extremely low overall disease prevalence in the surveyed area $(<1 \%)$, the large number of different scleractinian genera affected and the widespread distribution of BBD indicate a need for further investigation.
\end{abstract}

KEY WORDS: Coral diseases - Republic of Maldives - Black band disease - Disease prevalence Host range $\cdot$ Psammocora

Resale or republication not permitted without written consent of the publisher

\section{INTRODUCTION}

Coral diseases represent a serious threat to reef ecosystems. In recent decades, outbreaks of emerging diseases have become more frequent, possibly due to global ocean warming and human activities, contributing substantially to the speed-up of coral loss and reef decline (Green \& Bruckner 2000, Rosenberg \& Ben-Haim 2002, Harvell et al. 2007, 2009), with dire consequences for coral populations and associated reef communities (Harvell et al. 2002, Sokolow 2009).

Black band disease (BBD) is considered one of the most important contributors to the decline of coral reefs worldwide (Sutherland et al. 2004). BBD is char- acterized by a darkly pigmented microbial mat predominantly composed of cyanobacteria (primarily Roseofilum reptotaenium [Casamatta et al. 2012] and secondarily Geitlerinema spp., Oscillatoria spp., and Leptolyngbya in the Caribbean [Myers et al. 2007] and Oscillatoria and Pseudoscillatoria in the IndoPacific and Red Sea [Sussman et al. 2006, Sato et al. 2009]) and sulphide-reducing (Desulfovibrio spp.) and -oxidizing (Beggiatoa spp.) bacteria (Rützler \& Santavy 1983, Richardson 1997, Frias-Lopez et al. 2003). As the disease progresses, a consolidated band that separates living tissue from recently denuded skeleton becomes evident (Sutherland et al. 2004). BBD causes structural damage to coral tissue, producing widespread necroses that constitute the 
main mechanism of cellular death (Ainsworth et al. 2007). BBD is known to affect at least 42 Caribbean and 57 Indo-Pacific coral species (Sutherland et al. 2004, Kaczmarsky 2006, Page \& Willis 2006). Although it is generally characterized by low prevalence (Edmunds 1991, Dinsdale 2000, Weil et al. 2002), BBD is nonetheless considered a serious threat to coral populations worldwide due to its persistence (Kuta \& Richardson 1996, Green \& Bruckner 2000, Sutherland et al. 2004, Kaczmarsky 2006, Page \& Willis 2006, Zvuloni et al. 2009), as it can affect the same reef for decades, leading to long-term mortality of susceptible coral species and, in general, producing long-term changes in coral community structure (Bruckner \& Bruckner 1997).

BBD was first reported from reefs of Belize and the Florida Keys (Antonius 1973), while the first records from the Indo-Pacific (Philippines and the Red Sea) date back to the beginning of the 1980s (Antonius 1985). The most extensive losses of reef-building corals caused by BBD outbreaks have been reported in the Wider Caribbean Region (Edmunds 1991, Bruckner \& Bruckner 1997) and the Great Barrier Reef (Sato et al. 2009). BBD is currently known to be present in most of the world's coral reefs, including the Indo-Pacific region, which encompasses about $91 \%$ of the world's coral reefs. However, most studies on BBD have been conducted in the Pacific Ocean, e.g. Indonesia, Japan, the Philippines, Hawaii, American Samoa, and the PRIA (US Pacific Remote Island Areas) islands (Raymundo et al. 2005, Aeby 2006, Kaczmarsky 2006, Haapkylä et al. 2007, Myers \& Raymundo 2009, Vargas-Ángel 2009, Weil et al. 2012). By contrast, there is no detailed information available for its diffusion in the Indian Ocean, and especially in the Republic of Maldives, where it was recorded only in 2010 (Montano et al. 2012b).

The Maldivian reefs are among the most speciesrich of the Indian Ocean, being inhabited by $>180$ zooxanthellate coral species belonging to 51 genera (Pichon \& Benzoni 2007). The major reef structures occupy an area of about $21000 \mathrm{~km}^{2}, 21.1 \%$ of which can be categorized as marine productive reef habitat (Naseer \& Hutcher 2004). Maldivian reefs have been recently affected by coral bleaching, which has caused mass coral mortality (up to $90 \%$ ) and has promoted the replacement of communities dominated by Acropora with communities dominated by Porites (Goreau et al. 2000). Most of the studies aimed at evaluating Maldivian reef health after these massmortality events focused on coral cover, recruitment, colony sizes, and species richness (Loch et al. 2002, 2004, Bianchi et al. 2006a,b, Lasagna et al. 2006,
2008, Pichon \& Benzoni 2007). By contrast, little attention has been paid to the possible role played by coral diseases in reef-building corals (Montano et al. 2012b, Seveso et al. 2012).

In the present study, we quantify the prevalence of $\mathrm{BBD}$ on 41 reefs of the Republic of Maldives, distributed among 6 islands belonging to 3 different atolls. This work, which constitutes the first assessment of BBD in this archipelago, is aimed at (1) investigating the distribution and host range of BBD, (2) comparing BBD prevalence between island and depth, (3) exploring the differences in susceptibility among genera, and (4) assessing the relationship between BBD prevalence and host density.

\section{MATERIALS AND METHODS}

The study was conducted in the central Republic of Maldives between October 2010 and October 2011. During this period (which spanned both the wet and dry seasons), the local monthly mean sea surface temperature (SST) was fairly constant, varying from 28.4 to $30.1^{\circ} \mathrm{C}$ (mean: $29.4 \pm 0.4^{\circ} \mathrm{C}$ ) (Fig. 1).

In total, we investigated 41 sites distributed on 6 islands (Fig. 2), namely Ihuru and Vabbinfaru (Malè Atoll), Adanga and Magoodhoo (Faafu Atoll), and Athuruga and Thudufushi (Ari Atoll). The islands measure from $0.5 \mathrm{~km}$ (Ihuru) to $3.5 \mathrm{~km}$ (Thudufushi) in length, including coralline reefs, which in all cases exhibit the features of typical low-energy reefs, with a luxuriant growth of coral and gentle slopes on all sides. We selected 4 to 8 sites per island, choosing them haphazardly among those that were accessible. We carried out surveys by snorkelling at the shallow

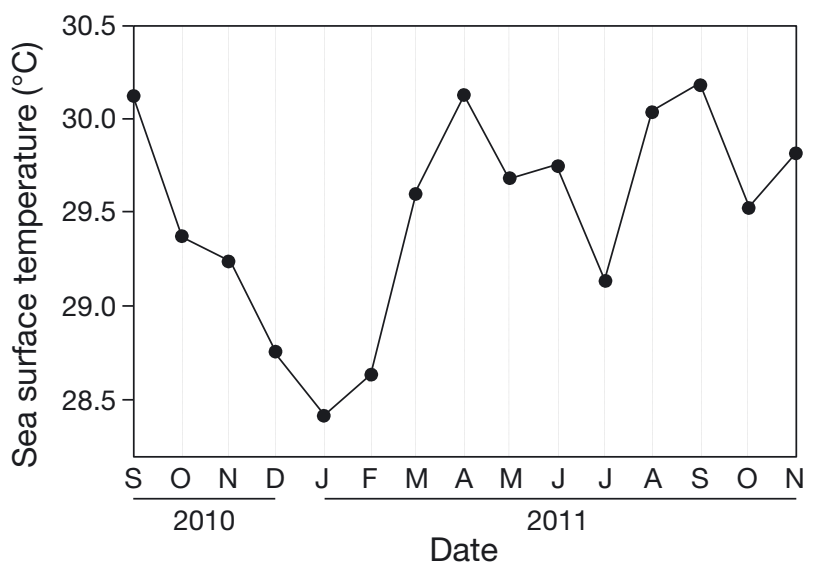

Fig. 1. Mean sea surface temperature in the area of Magoodhoo Island between September 2010 and November 2011 (source: http://disc.sci.gsfc.nasa.gov/techlab/giovanni/) 


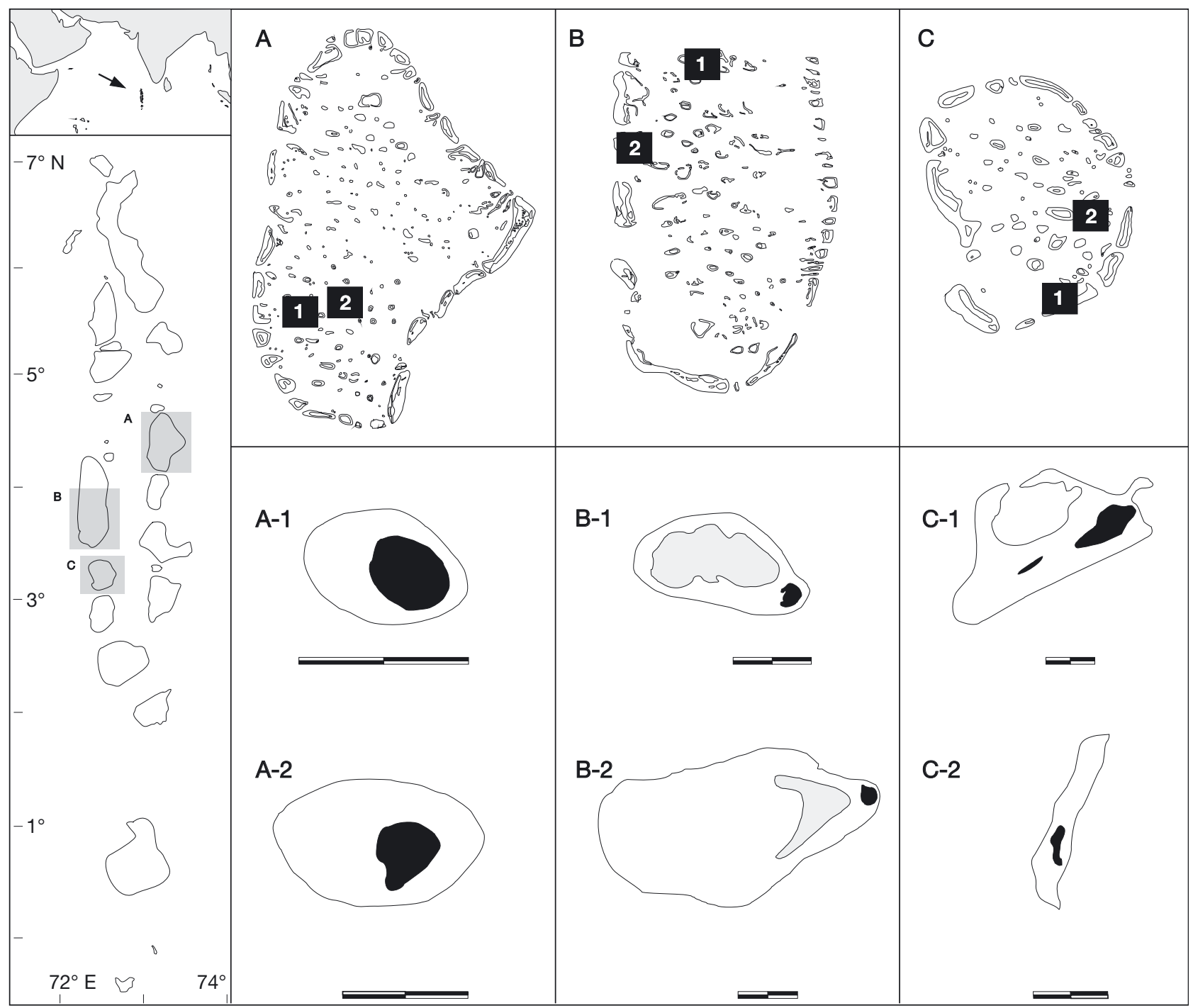

Fig. 2. Study area, located in the central Republic of Maldives (top left inset: location in the Indian Ocean; left vertical inset: Maldivian archipelago). A = Malè North Atoll (A-1 and A-2: Ihuru and Vabbinfaru islands, respectively); B = Ari Atoll (B-1 and B-2: Athuruga and Thudufushi islands, respectively); $\mathrm{C}=$ Faafu Atoll (C-1 and C-2: Magoodhoo and Adanga islands, respectively). In the lower panels, solid lines = reef limits, black areas = land, and grey areas = lagoons. Scale bars $=0.5 \mathrm{~km}$

sites $(\mathrm{n}=21$, depth: 0 to $5 \mathrm{~m})$ and SCUBA-diving at the deep ones ( $\mathrm{n}=20$, depth: 5 to $15 \mathrm{~m})$. We collected quantitative information about BBD prevalence by placing at each site 3 randomly placed $25 \times 1 \mathrm{~m}$ belt transects spaced 10 to $20 \mathrm{~m}$ apart. This sampling protocol was previously shown to be useful in the same area of study (see Montano et al. 2012b). We identified all corals to genus level in situ, according to Veron (2000). We counted colonies on the belt margins only when $50 \%$ or more of them lay within the belt boundaries. For each belt transect, we took note of the total number of healthy and diseased colonies in order to compute the disease prevalence (the ratio of the number of infected colonies to the total number of observed colonies). For each transect, we computed both an overall BBD prevalence value and a series of taxon-specific BBD prevalence values, calculated as the ratio between the number of diseased coral colonies belonging to a particular genus, and the total number of observed colonies belonging to that genus. Then we computed overall and taxonspecific prevalence values for each site by averaging the corresponding prevalence values measured in the 3 random belt transects.

We identified colonies affected by BBD according to Beeden et al. (2008) and Willis et al. (2004). For 
documentation purposes, we took underwater photographs of infected colonies using a Canon G11 camera in a Canon WP-DC 34 underwater housing (see Fig. 3 for lesion description).

Statistical comparisons of the disease prevalence of BBD between depths, islands, atolls, and scleractinian families were made using the Mann-Whitney $U$ test and the Kruskal-Wallis test because data failed to meet the normality assumption (Zar 1999). Spearman's rank correlation was used to examine if diseases and taxon-specific prevalence was related to host and overall coral density. Statistical analyses were performed using SPSS computer software. All data are presented as arithmetic mean \pm standard error (SE) unless otherwise stated.

\section{RESULTS}

We examined 6 islands belonging to 3 different atolls, performing 123 belt transects (covering $\sim 3075 \mathrm{~m}^{2}$ ). We found colonies affected by BBD in 46 transects $(37.4 \%)$ belonging to 27 sites $(65.9 \%)$ distributed among all islands. Most of the transects where we detected BBD (78.3\%) were at a depth ranging from 0 to $5 \mathrm{~m}$, while a few $(21.7 \%)$ were at a depth ranging from 5 to $15 \mathrm{~m}$.

In the investigated area, we examined 30284 colonies belonging to 23 scleractinian genera (Table 1). We found BBD in 74 colonies. The mean overall prevalence per site was $0.29 \pm 0.06 \%$. The highest BBD prevalence $(1.94 \%)$ was observed in a shallow site at Magoodhoo Island. We found a significant difference in the prevalence of BBD between shallow and deep sites (Mann-Whitney $U$-test, $\mathrm{p}<$ 0.01). In particular, the overall prevalence of BBD was much higher at shallow sites $(0.42 \pm 0.1 \%)$ than at deep ones $(0.14 \pm 0.2 \%)$. By contrast, we found no significant difference in prevalence between islands and between atolls. We detected a similar BBD prevalence $(<0.5 \%)$ on all islands. The highest value was observed at Magoodhoo Island $(0.42 \pm 0.23 \%)$. Regarding the atolls, the highest BBD prevalence was recorded at Faafu Atoll $(0.34 \pm 0.16 \%)$. At both Faafu Atoll and Ari Atoll, we detected significant differences in prevalence between shallow and deep sites (Mann-Whitney $U$-test, $\mathrm{p}<0.05$ ) (Fig. 4).

From a qualitative point of view, we detected BBD in 13 scleractinian genera belonging to 6 families (Acroporidae, Faviidae, Poritidae, Siderastreidae, Agariciidae, Fungiidae), but we did not detect it in soft or hydroid corals. We observed diseased colonies belonging to Gardineroseris sp. and Sandalolitha sp.
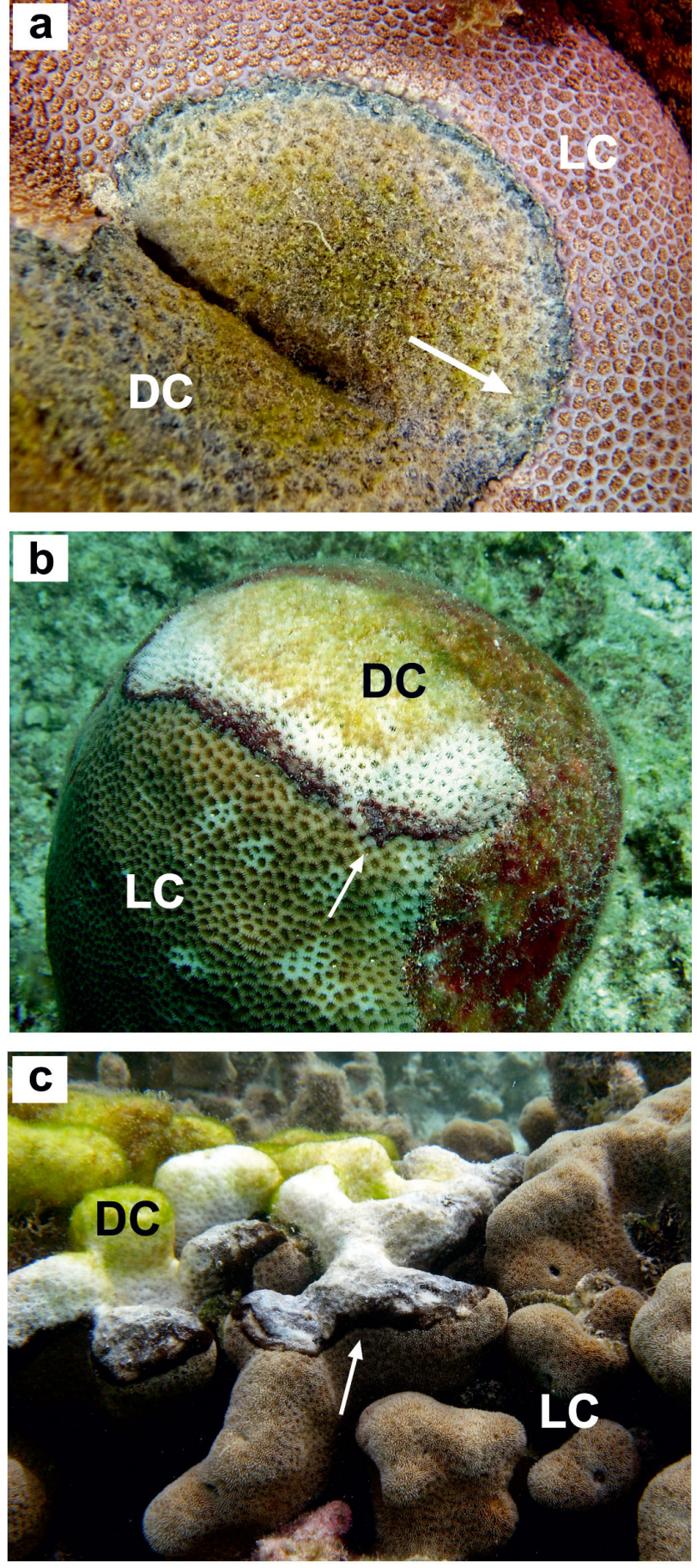

Fig. 3. (a) Goniopora sp., (b) Goniastrea sp., and (c) Psammocora digitata. In situ photographs showing the typical morphological features of black band disease (BBD) in the area of study (see Fig. 2). BBD is characterized by black linear or annular bands (5 to $30 \mathrm{~mm}$ wide; $\sim 1 \mathrm{~mm}$ thick) that move across the surface of coral colonies, actively degrading and eventually killing coral tissue, exposing intact coral skeleton. Apparently healthy tissue (live coral, LC) is separated by a dark mat constituting the black band (arrow), from the bare coral skeleton (dead coral, DC), sometimes covered by algae. Photos by S. Montano and D. Seveso 
Table 1. All sampled scleractinan genera and their relative abundance, black band disease (BBD) prevalence, and Spearman's $\rho$ values assessing correlation between host BBD prevalence and host coral density to genus level. ${ }^{*} \mathrm{p}<0.05,{ }^{* *} \mathrm{p}<0.01 . \times=$ diseased colonies not found within the transects. $\mathrm{nd}=$ not detected

\begin{tabular}{|c|c|c|c|c|}
\hline \multirow{2}{*}{$\begin{array}{l}\text { Family } \\
\text { Genus }\end{array}$} & \multirow{2}{*}{$\begin{array}{c}\text { Relative } \\
\text { abundance }\end{array}$} & \multicolumn{2}{|c|}{ BBD prevalence (\%) } & \multirow[t]{2}{*}{ Spearman's $\rho$} \\
\hline & & Maximum & Mean $\pm \mathrm{SE}$ & \\
\hline \multicolumn{5}{|l|}{ Acroporidae } \\
\hline Acropora & 53.36 & 1.3 & $0.07 \pm 0.03$ & -0.092 \\
\hline Astreopora & 0.08 & nd & nd & nd \\
\hline Isopora & 2.02 & 33.3 & $0.95 \pm 0.81$ & $0.420^{* *}$ \\
\hline Montipora & 2.18 & 5.53 & $0.13 \pm 0.13$ & 0.21 \\
\hline \multicolumn{5}{|l|}{ Agariciidae } \\
\hline Gardineroseris & 0.08 & $x$ & $\times$ & nd \\
\hline Pavona & 18.14 & 4 & $0.12 \pm 0.09$ & -0.203 \\
\hline \multicolumn{5}{|l|}{ Dendrophyllidae } \\
\hline Turbinaria & 0.02 & nd & nd & nd \\
\hline \multicolumn{5}{|l|}{ Faviidae } \\
\hline Favia & 0.9 & 11.1 & $0.27 \pm 0.27$ & -0.08 \\
\hline Favites & 1.95 & 1.38 & $0.03 \pm 0.03$ & 0.201 \\
\hline Cyphastrea & 0.02 & nd & nd & nd \\
\hline Echinopora & 0.06 & nd & nd & nd \\
\hline Goniastrea & 2.36 & 13.9 & $0.74 \pm 0.37$ & 0.289 \\
\hline Leptoria & 0.45 & nd & nd & nd \\
\hline \multicolumn{5}{|l|}{ Fungiidae } \\
\hline Fungia & 2.12 & 4.72 & $0.11 \pm 0.11$ & 0.242 \\
\hline Sandalolitha & 0 & $\times$ & $\times$ & nd \\
\hline \multicolumn{5}{|l|}{ Merulinidae } \\
\hline Hydnophora & 0.2 & nd & nd & nd \\
\hline \multicolumn{5}{|l|}{ Mussidae } \\
\hline Acanthastrea & 0.02 & nd & nd & nd \\
\hline Lobophyllia & 0.01 & nd & nd & nd \\
\hline Simphyllia & 0.01 & nd & nd & nd \\
\hline \multicolumn{5}{|l|}{ Pocilloporidae } \\
\hline Pocillopora & 5.16 & nd & nd & nd \\
\hline \multicolumn{5}{|l|}{ Poritidae } \\
\hline Goniopora & 0.86 & 41.6 & $2.73 \pm 1.36$ & $0.376^{*}$ \\
\hline Porites & 7.02 & 5.5 & $0.41 \pm 0.2$ & -0.085 \\
\hline \multicolumn{5}{|l|}{ Siderastreidae } \\
\hline Psammocora & 2.98 & 33.3 & $5.33 \pm 1.41$ & $0.335^{*}$ \\
\hline
\end{tabular}

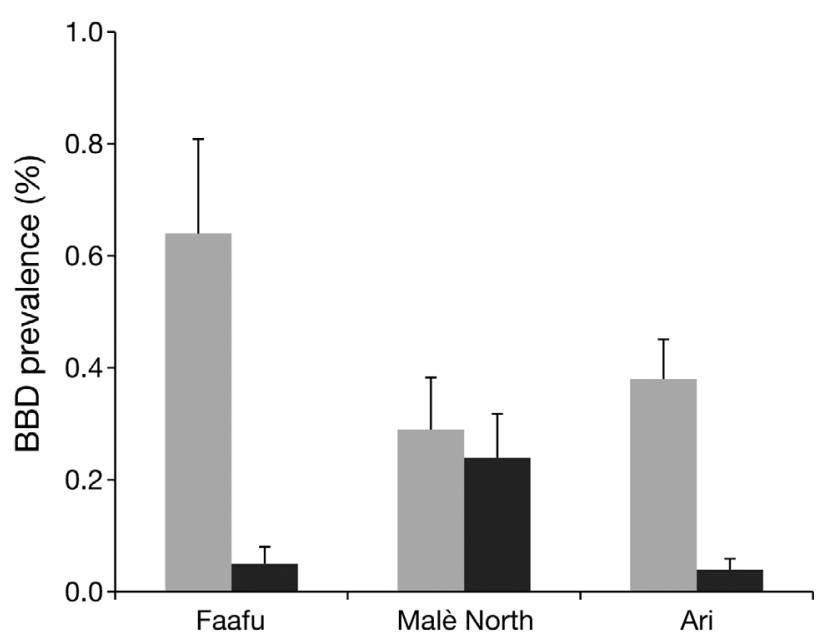

Fig. 4. Mean ( \pm SE) black band disease (BBD) prevalence by depth (grey bar $=$ shallow sites; black bar $=$ deep sites) for

depth $($ grey bar $=$ shallow sites; bla in the area of study but not within our transects; thus we did not include this information in the quantitative analyses. We detected a significant difference in BBD prevalence between families (Kruskal-Wallis $H(4)=10.532, \mathrm{p}<$ 0.05) (Fig. 5). The highest mean BBD prevalence was observed in the Siderastreidae $(5.33 \pm 1.41 \%)$, with a maximum of $33.3 \%$. On the other hand, acroporid corals showed the lowest mean prevalence $(0.09 \pm$ $0.03 \%$ ), with a maximum of $1.2 \%$. Species belonging to Siderastreidae were the most susceptible, with $48.6 \%$ of all infections found on species within this family. Pooling data across sites, we found that most of the diseased Siderastreidae colonies (47.2\%) belonged to the species Psammocora digitata. Sixteen percent of BBD infections were recorded from coral species belonging to both Poritidae and Acroporidae, $12.1 \%$ were recorded from species belonging to Faviidae, while the remaining percentage of infections were recorded from Agariciidae (4.1\%) and Fungiidae $(2.7 \%)$ corals. As regarding coral genera, BBD prevalence ranged from $0.03 \pm 0.03 \%$ (Favites) to $5.33 \pm 1.41 \%$ (Psammocora) (Table 1). The highest prevalence was observed in Goniopora (41.6 $\pm 52 \%$; mean $\pm \mathrm{SD})$, particularly at a shallow site at Ihuru Island (Malè North Atoll). Psammocora was the only genus that showed a

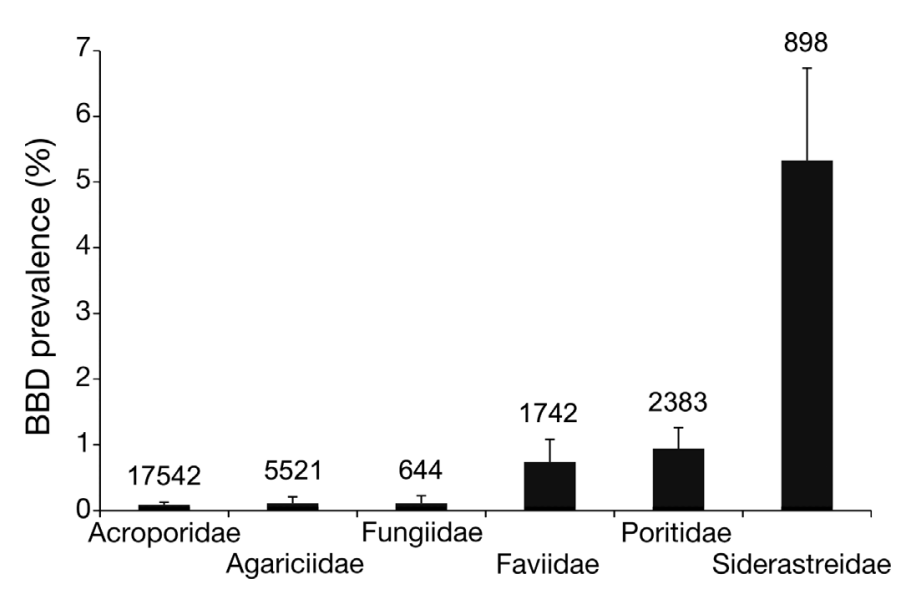

Fig. 5. Mean $( \pm \mathrm{SE}$ ) black band disease (BBD) prevalence and total number of colonies counted for each affected scleractinian family 

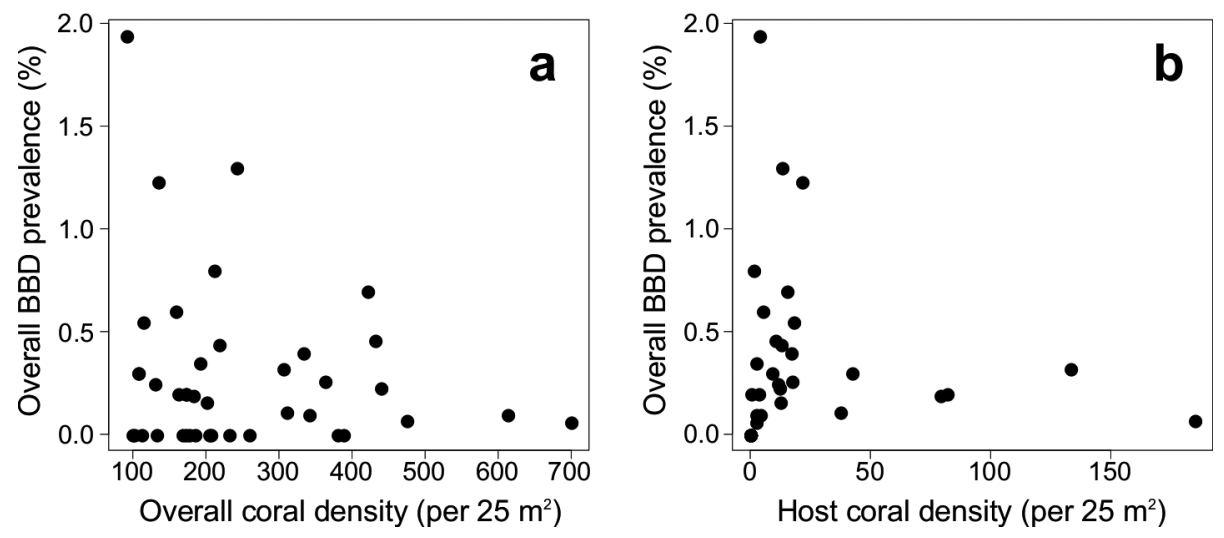

Fig. 6. Relationship between (a) overall black band disease (BBD) prevalence and overall coral density, and (b) overall BBD prevalence and host density

significant difference between depths (Mann-Whitney $U$-test, $\mathrm{p}<0.001)$. In general, we found a significant difference in coral density between shallow and deep sites (Mann-Whitney $U$-test, $\mathrm{p}<0.05$ ), with the shallow ones showing the highest coral density. We detected no significant relationship between overall BBD prevalence and overall coral density, but we found a significant positive correlation between overall disease prevalence and host density (Spearman's $\rho=0.695, p<0.01$ ) (Fig. 6). At genus level, however, a significant positive correlation between host density and host prevalence was detected only for Goniopora (Spearman's $\rho=0.376, \mathrm{p}<0.05$ ), Isopora (Spearman's $\rho=0.420, \mathrm{p}<0.01$ ), and Psammocora (Spearman's rho $\rho=0.335, \mathrm{p}<0.05)$ (Table 1 ).

\section{DISCUSSION}

Qualitative and quantitative patterns of coral disease presence, host range, prevalence, and epidemiology are largely unexplored in the Indian Ocean (Weil et al. 2012). The present study is the first assessment of BBD in the Republic of Maldives, which should be considered an area of particular interest due to the peculiar ecological features of the West Indo-Pacific Realm, which differs significantly in coral species diversity and distribution from regions farther east (Obura 2012). These differences may be related to large-scale biogeographical patterns (such as those promoted by the mid-Indian barrier; Bellwood \& Wainwright 2002) that, in combination with ecological specialization, may affect the distribution of several marine taxa (Strona et al. 2011).

In the present study, we found coral colonies affected by BBD at all 6 islands (belonging to 3 differ- ent atolls) that we investigated. Considering that this study represents a first assessment and that we selected sampling sites completely at random with respect to environmental and ecological features, our results may indicate that BBD is widely distributed in the Maldivian archipelago. From a quantitative perspective, our survey revealed a very low BBD prevalence, which is consistent with the general low BBD prevalence already reported in most reef regions (Dinsdale 2000, Weil et al. 2002, Page \& Willis 2006, Myers \& Raymundo 2009). Although during our study, no outbreaks were observed, the high BBD prevalence observed in Psammocora emphasizes the need for monitoring future BBD epizootic events. In fact, even if only a few BBD outbreaks have been observed in the Indo-Pacific region (Kaczmarsky 2006, Sato et al. 2009), many others have been reported from other areas (Brandt et al. 2012, 2013), and are often associated with global reef decline (Miller et al. 2009).

We observed the highest BBD prevalence in Magoodhoo, an inhabited island belonging to Faafu Atoll. This is not surprising, considering that some reefs around Magoodhoo should be considered to be in an unhealthy condition similar to the 'state of regression' recently reported for many other Maldivian reefs (Lasagna et al. 2010), which are characterized by a low coverage of living corals and high amounts of rubble and sand. In particular, the reefs around Magoodhoo Island are partly degraded and partly affected by overgrowth of macroalgae (Montano et al. 2012a) that has promoted loss of coral cover and an increase in rubble and sand (authors' pers. obs.). Human activities, such as aquaculture (Harvell et al. 1999) and fishing (Pandolfi et al. 2005), may alter environmental conditions on reefs and potentially reduce coral resistance to microbial infec- 
tions or increase pathogen virulence (Harvell et al. 2002), by increasing nutrient availability (Kuta \& Richardson 2002, Bruno et al. 2003, Voss \& Richardson 2006), organic matter (Kuntz et al. 2005, Kline et al. 2006, Baker et al. 2007), sewage effluent (Kaczmarsky et al. 2005, Sekar et al. 2008), and introduced chemicals (Owen et al. 2002, Danovaro et al. 2008). Thus, we cannot exclude that the unhealthy conditions of some Magoodhoo reefs may be partly related to human activities conducted on inhabited islands.

From an ecological perspective, we found that shallow coral colonies are more susceptible to diseases than deep ones. Several studies have already suggested that interactions among many environmental factors affect BBD abundance, including seawater temperature, water depth, solar irradiance, host population diversity, and anthropogenic nutrients (Al-Moghrabi 2001, Kuta \& Richardson 2002, Kaczmarsky et al. 2005). The prevalence of BBD has a well-documented seasonal cycle, and is positively influenced by water temperatures exceeding $28^{\circ} \mathrm{C}$ (Rützler et al. 1983, Kuta \& Richardson 2002). Distribution patterns and progression of BBD are also significantly affected by temperature and light (Kuta \& Richardson 2002, Boyett et al. 2007, Sato et al. 2009). In the area of study, the BBD consortium was dominated by photosynthetic cyanobacteria. Moreover, during the whole sampling period, the monthly average SST remained constantly above $28^{\circ} \mathrm{C}$ (Fig. 1). The combination of these 2 circumstances may have promoted coral susceptibility to BBD infections in the shallow water. Yet, further research is needed to investigate the effects of temperature and light on BBD in the Maldives, since we cannot exclude that they could somehow differ from those observed in other regions.

It should be noted that not all benthonic cnidarians are susceptible to BBD. Only a few surveys have reported cases of BBD in soft and hydroid corals, and the presence of BBD in these hosts seems to be particularly uncommon in the Indo-Pacific (Sutherland et al. 2004, Page \& Willis 2006). In our study area, soft and hydroid corals were so rare that we did not take them into account from a quantitative point of view. However, during our survey, no soft or hydroid coral was found to be infected by BBD. This may be partly related to the fact that very low population densities make the transmission of BBD difficult. However, the available studies on coral diseases affecting IndoPacific cnidarians (gorgonians, soft corals, hydrocorals) suggest that, apart from low coverage $(<3 \%$; see McClanahan 2011), there are also other factors that probably contribute to the relative immunity of non- scleractinian corals in this area. The greater vulnerability of Indo-Pacific scleractinians to coral diseases in comparison to other cnidarians may also reflect the low levels of antimicrobial activity and secondary compounds found in their tissues, in particular when compared to the levels observed in octocorals (Koh 1997, Kelman et al. 1998, 2006). Antibiotic activity of bacteria resident in coral mucus plays an important role in controlling pathogenic microbes (Ritchie 2006). Moreover, soft corals are capable of producing high levels of secondary metabolites that have antimicrobial activity and inhibit predation and overgrowth by algae (Sammarco \& Coll 1988, MichalekWagner \& Willis 2001).

Among the families, the Acroporidae were the least affected. This is consistent with previous observations in the Caribbean (Rützler et al. 1983, Antonius 1988), where a very low BBD prevalence was observed in the Acroporidae family. Still, this result is quite remarkable, considering that this family is usually highly susceptible (Sutherland et al. 2004, RuizMoreno et al. 2012) and often heavily affected by BBD (e.g. the Great Barrier Reef; Dinsdale 2000, Page \& Willis 2006). On the other hand, the Siderastreidae was the most affected family in our survey. Again, this is consistent with patterns previously observed in both the Caribbean and the Indo-Pacific region (Ruiz-Moreno et al. 2012).

In total, we detected BBD in 13 scleractinian genera (representing about the $25 \%$ of the total number of known genera for the entire archipelago). To date, BBD has not been reported in the genera Gardineroseris and Sandalolitha (Sutherland et al. 2004, Kaczmarsky 2006, Page \& Willis 2006); thus our results extend its global host range. The least affected genus was Favites, immediately followed by the fast-growing coral Acropora genus. This is in contrast with other studies, and confirms the known variability in the response of Acropora to diseases (Page \& Willis 2006), possibly mediated by natural and/or anthropogenic local features (Bruno et al. 2007, Garren et al. 2009). For example, Acropora is one of the most common hosts for coral diseases in several Indo-Pacific regions, such as the Great Barrier Reef (Willis et al. 2004, Selig et al. 2006) and the Maldivian archipelago (Montano et al. 2012b). Nonetheless, the differences in susceptibility to diseases of the genus Acropora in different geographic areas could be simply explained by local differences in species composition. Thus, although we are aware of the difficulties in field identification of corals at low taxonomic levels, which limit most of the current investigation on coral diseases (includ- 
ing the present study) to the genus level, we would like to stress the importance of acquiring information on disease susceptibility at the species level in order to orient future management and conservation plans. Acropora is the dominant genus in the Maldivian reefs, with a coverage percentage higher than $40 \%$ (Tkachenko 2012). Moreover, it displays several different growth morphologies, it is present in a wide depth range (from 0.5 to $20 \mathrm{~m}$ ) (Bianchi et al. 1997), and it gives a fundamental contribution to the 3D complexity of reef structure (Lasagna et al. 2010). This stresses the importance of monitoring Acropora's health status, even if our results indicate that it is not very susceptible to BBD. By contrast, the genus Psammocora is one of the less abundant ones in the archipelago, and, at the same time, one of the most affected ones (with almost all of the diseased colonies belonging to the species $P$. digitata). Interestingly, we detected a positive correlation between the prevalence of BBD in Psammocora and Psammocora density, suggesting that BBD epidemiology is somehow influenced by host availability. Finally, the overall ecological vulnerability of $P$. digitata (ranked by the IUCN Red List as Near Threatened; IUCN 2011) should not be underestimated. In general, the present results, together with other recent studies (Montano et al. 2012, Seveso et al. 2012), highlight the need for further studies aimed at better understanding the coral epidemiological dynamics in the Maldivian archipelago.

Acknowledgements. This research was supported by the Banyan Tree Hotels and Resorts, Soneva Fushi Kunfunadhoo Resort, and Planhotel Group. We thank the Banyan Tree Maldives Marine Lab, the iDive Centre of Athuruga and Thudufushi, and the Soleni Dive Centre of Kunfunadhoo for logistical support. Finally, we especially thank D. Maggioni, F. Siena, S. Zunino, A. Timillero, G. Magni, and M. Moraitis for assistance in the field.

\section{LITERATURE CITED}

Aeby GS (2006) Baseline levels of coral disease in the Northwestern Hawaiian Islands. Atoll Res Bull 534:471-488

Ainsworth TD, Kamasky-Winter E, Loya Y, Hoegh-Guldberg O, Fine M (2007) Coral disease diagnostics: what's between a plague and a band? Appl Environ Microbiol 73:981-992

Al-Moghrabi S (2001) Unusual black band disease (BBD) outbreak in the northern tip of the Gulf of Aqaba (Jordan). Coral Reefs 19:330-331

Antonius A (1973) New observations of coral destruction in reefs. Proc Assoc Isl Mar Lab Caribb, Mayaguez 10:17 Available at: www.amlc-carib.org

Antonius A (1985) Coral disease in the Indo-Pacific: a first recording. PSZNI: Mar Ecol 6:197-218
Antonius A (1988) Black band disease behavior on Red Sea reef corals. Proc 6th Int Coral Reef Symp, Townsville 3: 145-150

Baker DM, MacAvoy SE, Kim K (2007) Relationship between water quality, $\delta^{15} \mathrm{~N}$, and aspergillosis of Caribbean sea fan corals. Mar Ecol Prog Ser 343:123-130

Beeden R, Willis BL, Raymundo LJ, Page CA, Weil E (2008) Underwater cards for assessing coral health on IndoPacific reefs. Coral Reef Targeted Research and Capacity Building for Management Program. Currie Communications, Melbourne

Bellwood DR, Wainwright PC (2002) The history and biogeography of fishes on coral reefs. In: Sale PF (ed) Coral reef fishes: dynamics and diversity in a complex ecosystem. Academic Press, San Diego, CA, p 5-32

Bianchi CN, Colantoni P, Geister J, Morri C (1997) Reef geomorphology, sediments and ecological zonation at Felidu Atoll, Maldive Island (Indian Ocean). Proc 8th Int Coral Reef Symp, Panamà 1:431-436

Bianchi CN, Morri C, Pichon M, Benzoni F, Colantoni P, Baldelli G, Sandrini M (2006a) Dynamics and pattern of coral recolonization following the 1998 bleaching event in the reefs of the Maldives. Proc 10th Int Coral Reef Symp, Tokyo 1:30-37

Bianchi CN, Pichon M, Morri C, Colantoni P, Benzoni F, Baldelli G, Sandrini M (2006b) Le suivi du blanchissement des coraux aux Maldives: leçons à tirer et nouvelles hypothèses. Oceanis 29:325-354

Boyett HV, Bourne DG, Willis BL (2007) Elevated temperature and light enhance progression and spread of black band disease on staghorn corals of the Great Barrier Reef. Mar Biol 151:1711-1720

> Brandt ME, Ruttenberg BI, Waara R, Miller J, Witcher B, Estep AJ, Patterson M (2012) Dynamics of an acute coral disease outbreak associated with the macroalgae Dictyota spp. in Dry Tortugas National Park, Florida, U.S.A. Bull Mar Sci 88:1035-1050

> Brandt ME, Smith TB, Correa AMS, Vega-Thurber R (2013) Disturbance driven colony fragmentation as a driver of a coral disease outbreak. PLoS ONE 8:e57164

Bruckner AW, Bruckner RJ (1997) The persistence of blackband disease in Jamaica: impact on community structure. Proc 8th Int Coral Reef Symp, Panama 1:601-606

Bruno JF, Petes LE, Harvell CD, Hettinger A (2003) Nutrient enrichment can increase the severity of coral diseases. Ecol Lett 6:1056-1061

> Bruno JF, Selig ER, Casey KS, Page CA and others (2007) Thermal stress and coral cover as drivers of coral disease outbreak. PLoS Biol 5:e124

> Casamatta DA, Stani D, Gantar M, Richardson LL (2012) Characterization of Roseofilum reptotaenium (Cyanobacteria, Oscillatoriales) gen. et sp. nov. isolated from Caribbean black band disease. Phycologia 51:489-499

Danovaro R, Bongiorni L, Corinaldesi C, Giovannelli E and others (2008) Sunscreens cause coral bleaching by promoting viral infections. Environ Health Perspect 116: 441-447

Dinsdale EA (2000) Abundance of black-band disease on corals from one location on the Great Barrier Reef: a comparison with abundance in the Caribbean region. Proc 9th Int Coral Reef Symp, Bali 2:1239-1243

Edmunds PJ (1991) Extent and effect of black-band disease on a Caribbean reef. Coral Reefs 10:161-165

Frias-Lopez J, Bonheyo GT, Jin Q, Fouke BW (2003) Cyanobacteria associated with coral black band disease in 
Caribbean and Indo-Pacific reefs. Appl Environ Microbiol 69:2409-2413

Garren M, Raymundo L, Guest J, Harvell CD, Azam F (2009) Resilience of coral-associated bacterial communities exposed to fish farm effluent. PLoS ONE 4:e7319

Goreau T, McClanahan TR, Hayes R, Strong A (2000) Conservation of coral reefs after the 1998 global bleaching event. Conserv Biol 14:5-15

Green EP, Bruckner AW (2000) The significance of coral disease epizootiology for coral reef conservation. Biol Conserv 96:347-361

Haapkylä J, Seymour AS, Trebilco J, Smith D (2007) Coral disease prevalence and coral health in the Wakatobi Marine Park, South-East Sulawesi, Indonesia. J Mar Biol Assoc UK 87:403-414

Harvell CD, Kim K, Burkholder JM, Colwell RR and others (1999) Emerging marine diseases: climate links and anthropogenic factors. Science 285:1505-1510

Harvell CD, Mitchell CE, Ward JR, Altizer S, Dobson AP, Ostfeld RS, Samuel MD (2002) Climate warming and disease risk for terrestrial and marine biota. Science 296: 2158-2162

> Harvell CD, Jordán-Dahlgren E, Merkel S, Rosenberg E and others (2007) Coral disease, environmental driver and the balance between coral and microbial associates. Oceanography (Wash DC) 20:172-195

> Harvell CD, Altize SR, Cattadori IM, Harrington L, Weil E (2009) Climate change and wildlife diseases: When does the host matter the most? Ecology 90:912-920

IUCN (2011) IUCN Red List of Threatened Species. Version 2011.2. Available at: www.iucnredlist.org

> Kaczmarsky LT (2006) Coral disease dynamics in the central Philippines. Dis Aquat Org 69:9-21

Kaczmarsky L, Draud M, Williams EH (2005) Is there a relationship between proximity to sewage effluent and the prevalence of coral disease? Caribb J Sci 41:124-137

Kelman D, Kushmaro A, Loya Y, Kashman Y, Benayahu Y (1998) Antimicrobial activity of a Red Sea soft coral, Parerythropodium fulvum fulvum: reproductive and developmental considerations. Mar Ecol Prog Ser 169:87-95

> Kelman D, Kashman Y, Rosenberg E, Kushmaro A, Loya Y (2006) Antimicrobial activity of Red Sea corals. Mar Biol 149:357-363

Kline DI, Kuntz NM, Breitbart M, Knowlton N, Rohwer F (2006) Role of elevated organic carbon levels and microbial activity in coral mortality. Mar Ecol Prog Ser 314: 119-125

Koh EGL (1997) Do scleractinian corals engage in chemical warfare against marine microbes? J Chem Ecol 23: 379-398

> Kuntz NM, Kline DI, Sandin SA, Rohwer F (2005) Pathologies and mortality rates caused by organic carbon and nutrient stressors in three Caribbean coral species. Mar Ecol Prog Ser 294:173-180

Kuta KG, Richardson LL (1996) Abundance and distribution of black band disease on coral reefs in the northern Florida Keys. Coral Reefs 15:219-223

Kuta K, Richardson L (2002) Ecological aspects of black band disease of corals: relationships between disease incidence and environmental factors. Coral Reefs 21: 393-398

Lasagna R, Gattorna I, Albertelli G, Morri C, Bianchi CN (2006) Eterogeneità del substrato e relazione con il reclutamento dei coralli in scogliere coralline delle Maldive (Oceano Indiano). Biol Mar Mediterr 13:88-89
Lasagna R, Albertelli G, Giovannetti E, Grondona M, Milani A, Morri C, Bianchi CN (2008) Status of Maldivian reefs eight years after the 1998 coral mass mortality. Chem Ecol 24(Suppl 1):67-72

> Lasagna R, Albertelli G, Morri C, Bianchi CN (2010) Acropora abundance and size in the Maldives six years after the 1998 mass mortality: patterns across reef typologies and depths. J Mar Biol Assoc UK 90:919-922

> Loch K, Loch W, Schuhmacher H, See WR (2002) Coral recruitment and regeneration on a Maldivian reef 21 months after the coral bleaching event of 1998. PSZNI: Mar Ecol 23:219-236

> Loch K, Loch W, Schuhmacher H, See WR (2004) Coral recruitment and regeneration on a Maldivian reef four years after the coral bleaching event of 1998. Part 2: 2001-2002. PSZNI: Mar Ecol 25:145-154

> McClanahan TR (2011) Coral reef fish communities in management systems with unregulated fishing and small fisheries closures compared with lightly fished reefs Maldives vs. Kenya. Aquat Conserv: Mar Freshw Ecosyst 21:186-198

> Michalek-Wagner K, Willis BL (2001) Impacts of bleaching on the soft coral Lobophytum compactum. I. Fecundity, fertilization and offspring viability. Coral Reefs 19: 231-239

Miller J, Muller EM, Rogers C, Waara R and others (2009) Coral disease following massive bleaching in 2005 causes $60 \%$ decline in coral cover on reefs in the US Virgin Islands. Coral Reefs 28:925-937

Montano S, Seveso D, Strona G, Galli P (2012a) Acropora muricata mortality associated with extensive growth of Caulerpa racemosa in Magoodhoo Island, Republic of Maldives. Coral Reefs 31:793

Montano S, Strona G, Seveso D, Galli P (2012b) First report of coral diseases in the Republic of Maldives. Dis Aquat Org 101:159-165

Myers RL, Raymundo LJ (2009) Coral disease in Micronesian reefs: a link between disease prevalence and host abundance. Dis Aquat Org 87:97-104

> Myers JL, Sekar R, Richardson L (2007) Molecular detection and ecological significance of the Cyanobacterial genera Geitlerinema and Leptolyngbya in black band disease of corals. Appl Environ Microbiol 73:5173-5182

Naseer A, Hutcher BG (2004) Inventory of the Maldive's coral reefs using morphometrics generated from Landsat ETM+ imagery. Coral Reefs 23:161-168

> Obura D (2012) The diversity and biogeography of Western Indian Ocean reef-building corals. PLoS ONE 7: e45013

> Owen R, Knap AH, Toaspern M, Carbery K (2002) Inhibition of coral photosynthesis by the antifouling herbicide Irgarol 1051 ${ }^{\circledR}$. Mar Pollut Bull 44:623-632

> Page C, Willis B (2006) Distribution, host range and largescale spatial variability in black band disease prevalence on the Great Barrier Reef, Australia. Dis Aquat Org 69: 41-51

> Pandolfi JM, Jackson JBC, Baron N, Bradbury RH and others (2005) Are U.S. coral reefs on the slippery slope to slime? Science 307:1725-1726

Pichon M, Benzoni F (2007) Taxonomic re-appraisal of zooxanthellate scleractinian corals in the Maldive Archipelago. Zootaxa 1441:21-33

> Raymundo LJ, Rosell KB, Reboton CT, Karczmarsky L (2005) Coral diseases on Philippine reefs: genus Porites is a dominant host. Dis Aquat Org 64:181-191 
Richardson LL (1997) Occurrence of black band disease cyanobacterium on healthy corals of the Florida Keys. Bull Mar Sci 61:485-490

Ritchie KB (2006) Regulation of microbial populations by coral surface mucus and mucus-associated bacteria. Mar Ecol Prog Ser 322:1-14

Rosenberg E, Ben-Haim Y (2002) Microbial diseases of corals and global warming. Environ Microbiol 4:318-326

Ruiz-Moreno D, Willis BL, Page AC, Weil E and others (2012) Global coral disease prevalence associated with sea temperature anomalies and local factors. Dis Aquat Org 100:249-261

Rützler K, Santavy DL (1983) The black band disease of Atlantic reef corals. PSZNI: Mar Ecol 4:301-319

Rützler K, Santavy DL, Antonius A (1983) The black band disease of Atlantic reef corals. III. Distribution, ecology and development. PSZNI: Mar Ecol 4:329-358

Sammarco PW, Coll JC (1988) The chemical ecology of alcyonarian corals (Coelenterata: Octocorallia). In: Scheuer PJ (ed) Bioorganic marine chemistry, Vol 2. SpringerVerlag, Berlin, p 87-116

Sato Y, Bourne DG, Willis BL (2009) Dynamics of seasonal outbreaks of black band disease in an assemblage of Montipora species at Pelorus Island (Great Barrier Reef, Australia). Proc R Soc Lond B Biol Sci 276:2795-2803

Sekar R, Kaczmarsky LT, Richardson LL (2008) Microbial community composition of black band disease on the coral host Siderastrea siderea from three regions of the wider Caribbean. Mar Ecol Prog Ser 362:85-98

Selig ER, Harvell CD, Bruno JF, Willis BL, Page CA, Casey KS, Sweatman H (2006) Analyzing the relationship between ocean temperature anomalies and coral disease outbreaks at broad spatial scales. In: Phinney JT, Strong A, Skrving W, West J, Kleypas J, Hough-Guldberg O (eds) Coral reefs and climate change: science and management. Coastal and Estuarine Series, Vol 61. American Geophysical Union Press, Washington, DC, p 111-128

Seveso D, Montano S, Strona G, Orlandi I, Vai M, Galli P (2012) Up-regulation of Hsp60 in response to skeleton eroding band disease but not by algal overgrowth in the scleractinian coral Acropora muricata. Mar Environ Res 78:34-39

Editorial responsibility: Garriet Smith,

Aiken, South Carolina, USA
Sokolow S (2009) Effects of a changing climate on the dynamics of coral infectious disease: a review of the evidence. Dis Aquat Org 87:5-18

Strona G, Stefani F, Galli P, Fattorini S (2011) Reapproaching the centre of origin theory: a case study of siganid fishes (Actinistia: Siganidae). Vie Milieu 61: 71-76

Sussman M, Bourne DG, Willis BL (2006) A single cyanobacterial ribotype is associated with both red and black bands on diseased corals from Palau. Dis Aquat Org 69: $111-118$

> Sutherland KP, Porter JW, Torres C (2004) Disease and immunity in Caribbean and Indo-Pacific zooxanthellate corals. Mar Ecol Prog Ser 266:273-302

Tkachenko KS (2012) The northernmost coral frontier of the Maldives: the coral reefs of Ihavandippolu Atoll under long-term environmental change. Mar Environ Res 82: 40-48

Vargas-Ángel B (2009) Coral health and disease assessment in the U.S. Pacific Remote Island Areas. Bull Mar Sci 84: 211-227

Veron JEN (2000) Corals of the world, Vols 1-3. Australian Institute of Marine Science, Townsville

Voss JD, Richardson LL (2006) Nutrient enrichment enhances black band disease progression in corals. Coral Reefs 25:569-576

Weil E, Urreiztieta I, Garzón-Ferreira J (2002) Local and geographic variability in the incidence of disease in western Atlantic coral reefs. Proc 9th Int Coral Reef Symp, Bali 2:1231-1238

Weil E, Irikawa A, Casareto B, Suzuki Y (2012) Extended geographic distribution of several Indo-Pacific coral reef diseases. Dis Aquat Org 98:163-170

Willis BL, Page CA, Dindsdale EA (2004) Coral disease in the Great Barrier Reef. In: Rosenberg E, Loya Y (eds) Coral health and disease. Springer-Verlag, New York, NY, p 69-104

Zar JH (1999) Biostatistical analysis. Prentice-Hall, London Zvuloni A, Artzy-Randrup Y, Stone L, Kramarsky-Winter E, Barkan R, Loya Y (2009) Spatio-temporal transmission patterns of black-band disease in a coral community. PLoS ONE 4:e4993

Submitted: December 17, 2012; Accepted: April 9, 2013 Proofs received from author(s): June 18, 2013 